\title{
The Canadian Mineralogist
}

\section{FLUORAPOPHYLLITE-(Cs), $\mathrm{CsCa}_{4}\left(\mathrm{Si}_{8} \mathrm{O}_{20}\right) \mathrm{F}\left(\mathrm{H}_{2} \mathrm{O}\right)_{8}$, A NEW APOPHYLLITE-GROUP MINERAL FROM THE DARAI-PIOZ MASSIF, TIEN-SHAN, NORTHERN TAJIKISTAN --Manuscript Draft--}

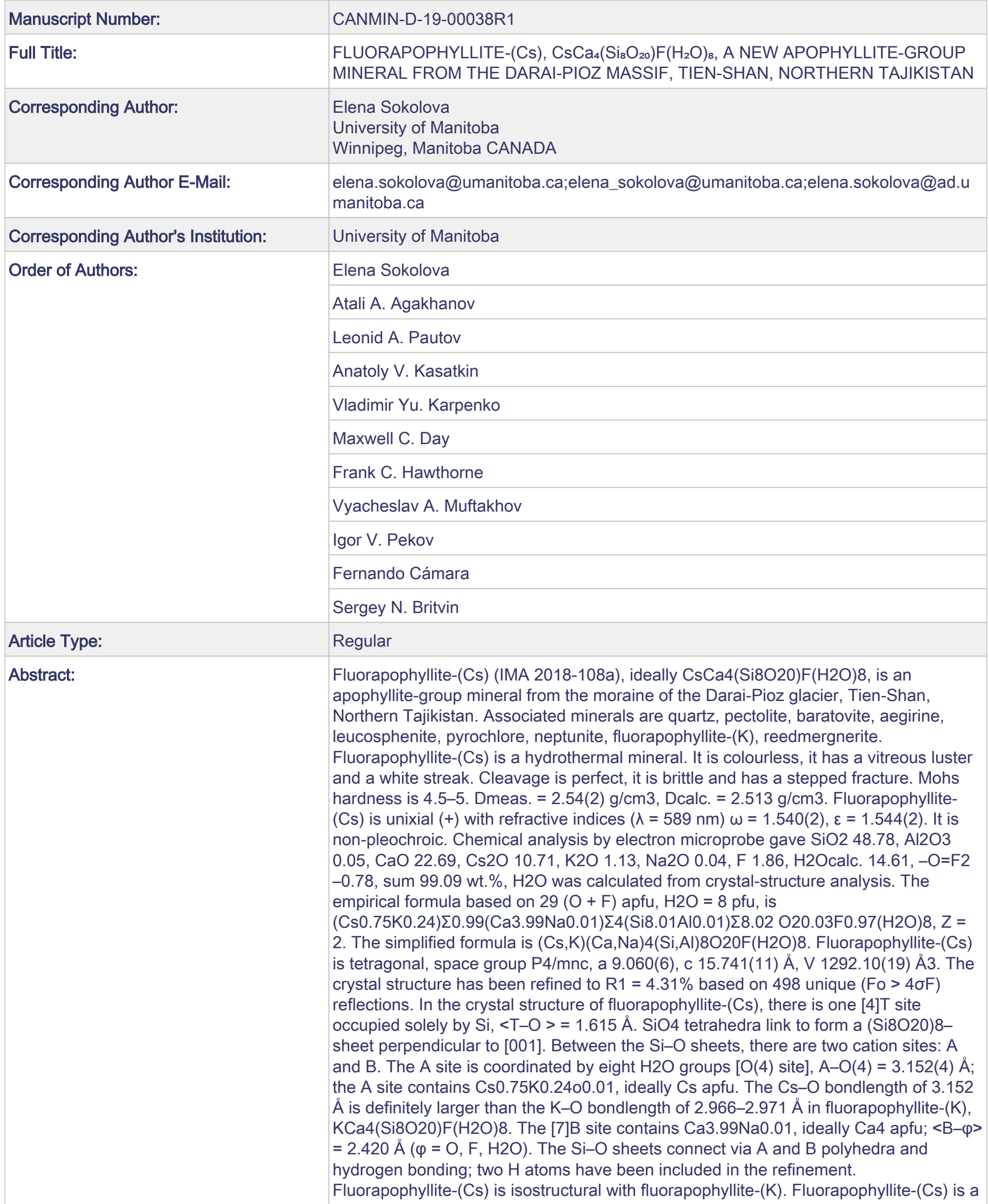


Cs-analogue of fluorapophyllite-(K).

Keywords:

fluorapophyllite-(Cs); new mineral; apophyllite group; Darai Pioz, Tien Shan, Northern Tajikistan; electron microprobe analysis; crystal structure

Author Comments: 


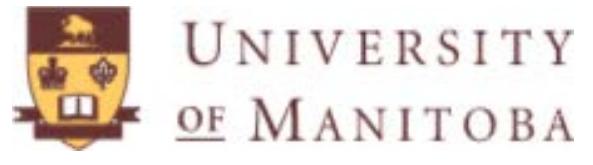

Dr. Lee A. Groat

Editor, The Canadian Mineralogist

Dept of Earth \& Ocean Science

University of British Columbia

6339 Stores Road

Vancouver BC V6T $1 Z 4$
Department of Geological Sciences 240 Wallace Bldg., 125 Dysart Rd. Winnipeg, Manitoba, Canada R3T 2N2

Phone (204) 474-9371

Fax (204) 474-7623

July 30, 2019

Dear Lee:

I am returning the revised manuscript No. CANMIN-D-19-00038:

"FLUORAPOPHYLLITE-(Cs), $\mathrm{CsCa}_{4}\left(\mathrm{Si}_{8} \mathrm{O}_{20}\right) \mathrm{F}\left(\mathrm{H}_{2} \mathrm{O}\right)_{8}$, A NEW APOPHYLLITE-GROUP MINERAL FROM THE DARAI-PIOZ MASSIF, TIEN-SHAN, NORTHERN TAJIKISTAN".

We found comments and suggestions made by Associate Editor James Evans and an anonymous reviewer constructive and corrected the manuscript accordingly.

Best Regards,

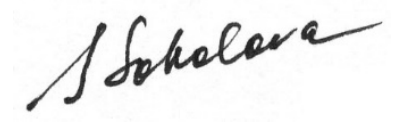

Elena Sokolova, Professor, Mineralogy 


\title{
FLUORAPOPHYLLITE-(Cs), $\mathrm{CsCa}_{4}\left(\mathrm{Si}_{8} \mathrm{O}_{20}\right) \mathrm{F}\left(\mathrm{H}_{2} \mathrm{O}\right)_{8}$, A NEW APOPHYLLITE-GROUP MINERAL FROM THE DARAI-PIOZ MASSIF, TIEN-SHAN, NORTHERN TAJIKISTAN
}

\author{
AtAli A. AGAKHANOV, LEONID A. PAUTOV, ANATOLY V. KASATKIN, VLADIMIR YU.

\section{KARPENKO} \\ Fersman Mineralogical Museum, Russian Academy of Sciences, Leninskii Prospekt, 18-2, \\ 119071 Moscow, Russia
}

\author{
ELENA SOKOLOVA*, MAXWELl C. DAY and FRANK C. HAWTHORNE \\ Department of Geological Sciences, University of Manitoba, \\ Winnipeg, Manitoba R3T 2N2 Canada
}

\author{
VYACHESLAV A. MUFTAKHOV \\ Institute of Mineralogy, the Ural branch, Russian Academy of Sciences, the Ilmen State Nature Reserve, \\ 456317 Miass, Russia \\ Faculty of Geology, National Research South Ural State University, Miass branch, 8 July Str., 10, \\ 456304 Miass, Russia \\ IGOR V. PEKOV \\ Department of Mineralogy, Moscow State University, Vorobievy Gory, 119991 Moscow, Russia \\ FERNANDO CÁMARA \\ Dipartimento di Scienze della Terra “Ardito Desio”, Università degli Studi di Milano, Via Mangiagalli \\ 34, 20133, Milano, Italy

\section{SERGEY N. BRITVIN} \\ Department of Crystallography, St.-Petersburg State University, University Emb. 7/9, 199034 St.- \\ Petersburg, Russia
}

Running title: FLUORAPOPHYLLITE-(Cs), A NEW APOPHYLLITE-GROUP MINERAL

*Corresponding author e-mail address: elena_sokolova@umanitoba.ca 


\begin{abstract}
Fluorapophyllite-(Cs) (IMA 2018-108a), ideally $\mathrm{CsCa}_{4}\left(\mathrm{Si}_{8} \mathrm{O}_{20}\right) \mathrm{F}\left(\mathrm{H}_{2} \mathrm{O}\right)_{8}$, is an apophyllite-group mineral from the moraine of the Darai-Pioz glacier, Tien-Shan, Northern Tajikistan. Associated minerals are quartz, pectolite, baratovite, aegirine, leucosphenite, pyrochlore, neptunite, fluorapophyllite-(K), reedmergnerite. Fluorapophyllite-(Cs) is a hydrothermal mineral. It is colourless, it has a vitreous luster and a white streak. Cleavage is perfect, it is brittle and has a stepped fracture. Mohs hardness is 4.5-5. $D_{\text {meas. }}=2.54(2) \mathrm{g} / \mathrm{cm}^{3}, D_{\text {calc. }}=2.513 \mathrm{~g} / \mathrm{cm}^{3}$. Fluorapophyllite- $(\mathrm{Cs})$ is unixial $(+)$ with refractive indices $(\lambda$ $=589 \mathrm{~nm}) \omega=1.540(2), \varepsilon=1.544(2)$. It is non-pleochroic. Chemical analysis by electron microprobe gave $\mathrm{SiO}_{2} 48.78, \mathrm{Al}_{2} \mathrm{O}_{3}$ 0.05, $\mathrm{CaO} 22.69, \mathrm{Cs}_{2} \mathrm{O} 10.71, \mathrm{~K}_{2} \mathrm{O}$ 1.13, $\mathrm{Na}_{2} \mathrm{O}$ 0.04, F 1.86, $\mathrm{H}_{2} \mathrm{O}_{\text {calc. }}$ 14.61, $-\mathrm{O}=\mathrm{F}_{2}$ -0.78 , sum 99.09 wt.\%, $\mathrm{H}_{2} \mathrm{O}$ was calculated from crystal-structure analysis. The empirical formula based on $29(\mathrm{O}+\mathrm{F})$ apfu, $\mathrm{H}_{2} \mathrm{O}=8 p f u$, is $\left(\mathrm{Cs}_{0.75} \mathrm{~K}_{0.24}\right)_{\Sigma 0.99}\left(\mathrm{Ca}_{3.99} \mathrm{Na}_{0.01}\right)_{\Sigma 4}\left(\mathrm{Si}_{8.01} \mathrm{Al}_{0.01}\right)_{\Sigma 8.02} \mathrm{O}_{20.03} \mathrm{~F}_{0.97}\left(\mathrm{H}_{2} \mathrm{O}\right)_{8}, Z=2$. The simplified formula is $(\mathrm{Cs}, \mathrm{K})(\mathrm{Ca}, \mathrm{Na})_{4}(\mathrm{Si}, \mathrm{Al})_{8} \mathrm{O}_{20} \mathrm{~F}\left(\mathrm{H}_{2} \mathrm{O}\right)_{8}$. Fluorapophyllite- $(\mathrm{Cs})$ is tetragonal, space group P4/mnc, a 9.060(6), c 15.741(11),$V$ 1292.10(19) $\AA^{3}$. The crystal structure has been refined to $R_{1}$ $=4.31 \%$ based on 498 unique $\left(F_{\mathrm{o}}>4 \sigma F\right)$ reflections. In the crystal structure of fluorapophyllite-(Cs), there is one ${ }^{[4]} T$ site occupied solely by $\mathrm{Si},\langle\mathrm{T}-\mathrm{O}\rangle=1.615 \AA$. $\mathrm{SiO}_{4}$ tetrahedra link to form a $\left(\mathrm{Si}_{8} \mathrm{O}_{20}\right)^{8-}$ sheet perpendicular to [001]. Between the $\mathrm{Si}-\mathrm{O}$ sheets, there are two cation sites: $A$ and $B$. The $A$ site is coordinated by eight $\mathrm{H}_{2} \mathrm{O}$ groups $\left[\mathrm{O}(4)\right.$ site], A-O(4) = 3.152(4) $\AA$; the $A$ site contains $\mathrm{Cs}_{0.75} \mathrm{~K}_{0.24} \square_{0.01}$, ideally Cs apfu. The Cs-O bondlength of $3.152 \AA$ is definitely larger than the K-O bondlength of 2.966$2.971 \AA$ A in fluorapophyllite-(K), $\mathrm{KCa}_{4}\left(\mathrm{Si}_{8} \mathrm{O}_{20}\right) \mathrm{F}\left(\mathrm{H}_{2} \mathrm{O}\right)_{8}$. The ${ }^{[7]} B$ site contains $\mathrm{Ca}_{3.99} \mathrm{Na}_{0.01}$, ideally $\mathrm{Ca}_{4}$ apfu; $\langle\mathrm{B}-\varphi\rangle=2.420 \AA\left(\varphi=\mathrm{O}, \mathrm{F}, \mathrm{H}_{2} \mathrm{O}\right)$. The $\mathrm{Si}-\mathrm{O}$ sheets connect via $\mathrm{A}$ and $\mathrm{B}$ polyhedra and hydrogen bonding; two H atoms have been included in the refinement. Fluorapophyllite-(Cs) is isostructural with fluorapophyllite-(K). Fluorapophyllite-(Cs) is a Cs-analogue of fluorapophyllite-(K).
\end{abstract}

Keywords: fluorapophyllite-(Cs), new mineral, apophyllite group, Darai-Pioz, Tien-Shan, Northern Tajikistan, electron microprobe analysis, crystal structure. 


\section{INTRODUCTION}

Fluorapophyllite-(Cs), ideally $\mathrm{CsCa}_{4}\left(\mathrm{Si}_{8} \mathrm{O}_{20}\right) \mathrm{F}\left(\mathrm{H}_{2} \mathrm{O}\right)_{8}$, is a new mineral of the apophyllite group (Dunn \& Wilson 1978, Hatert et al. 2013) from the moraine of the Darai-Pioz glacier, Tien-Shan, Northern Tajikistan. This locality is well-known for Cs-bearing minerals. Fluorapophyllite-(Cs) is named in accord with the current nomenclature of the apophyllite-group minerals (Hatert et al. 2013). The new mineral species and its name were approved by the Commission on New Minerals, Nomenclature and Classification, International Mineralogical Association (IMA 2018-108a). The holotype specimen of fluorapophyllite-(Cs) has been deposited in the collections of the Fersman Mineralogical Museum, Russian Academy of Sciences, Moscow, Russia, registration number 5280/1. Here we report the description and crystal structure of fluorapophyllite-(Cs), a new mineral.

\section{OCCURRENCE AND Mineral ASSOCiation}

Fluorapophyllite-(Cs) was found at the moraine of the Darai-Pioz glacier $\left(39^{\circ} 30^{\prime} \mathrm{N}\right.$ and $70^{\circ} 40^{\prime}$ E), the Alai mountain range, Tien-Shan, Rashtskii district, N. Tajikistan. The multiphase Darai-Pioz massif belongs to the Upper Paleozoic Alaysky (Matchaisky) intrusive complex. The area of outcrop of the massif is about $16 \mathrm{~km}^{2}$. Most of the massif rocks are covered by moraine or glaciers, and/or are difficult to access. In the north, the massif intrudes Silurian limestones and slates, and in the south, it intrudes terrigenous slates of Late Carboniferous age. The outer zone of the massif consists of subalkaline biotite granite, often tourmalinized (300-290 Ma), surrounding a discontinuous ring of biotite granites and granosyenites. The central part of massif comprises quartz and aegirine syenites. In the northeast part of the massif, there is a stock of cancrinite and nepheline foyaite ( $247 \pm 6 \mathrm{Ma})$. There are veins of syenite pegmatites and aegirine-potassium feldspar-quartz rocks containing polylithionite (286 $\pm 7 \mathrm{Ma})$ and raremetal and boron mineralization. Veins of calcite carbonatites and syenite carbonatites (Faiziev et al. 2010) are widespread. Much of the rock is fenitized to different degrees. Detailed descriptions of the petrography and mineralogy of the Darai-Pioz massif can be found in Moskvin (1937), Dusmatov (1968, 1971), Semenov \& Dusmatov (1975), Belakovskiy (1991) and Reguir et al. (1999). 
This locality is known for Cs-bearing minerals. Kupletskite-(Cs) was the first Cs-bearing mineral described from Darai-Pioz (Yefimov et al. 1971, Cámara et al. 2010). In the last five years, five Csbearing minerals have been decribed from Darai-Pioz: odigitriaite, $\mathrm{CsNa}_{5} \mathrm{Ca}_{5}\left[\mathrm{Si}_{14} \mathrm{~B}_{2} \mathrm{O}_{38}\right] \mathrm{F}_{2}$ (IMA 2015028, Agakhanov et al. 2017a); mendeleevite-(Nd), (Cs, $\square)_{6}(\square, \mathrm{Cs})_{6}(\square, \mathrm{K})_{6}(\operatorname{REE}, \mathrm{Ca})_{30}\left(\mathrm{Si}_{70} \mathrm{O}_{175}\right)$

$\left(\mathrm{OH}, \mathrm{H}_{2} \mathrm{O}, \mathrm{F}\right)_{35}$ (IMA 2015-031, Agakhanov et al. 2017b); two Cs-micas: garmite, $\mathrm{CsLiMg} \mathrm{Mg}_{2}\left(\mathrm{Si}_{4} \mathrm{O}_{10}\right) \mathrm{F}_{2}$ (IMA 2017-008, Pautov et al. 2017) and gorbunovite, $\mathrm{CsLi}_{2}(\mathrm{Ti}, \mathrm{Fe})\left(\mathrm{Si}_{4} \mathrm{O}_{10}\right)(\mathrm{F}, \mathrm{OH}, \mathrm{O})_{2}(\mathrm{IMA} 2017-040$, Agakhanov et al. 2017c); fluorapophyllite-(Cs), $\mathrm{CsCa}_{4}\left(\mathrm{Si}_{8} \mathrm{O}_{20}\right) \mathrm{F}\left(\mathrm{H}_{2} \mathrm{O}\right)_{8}$ (IMA 2018-108a, this work).

Fluorapophyllite-(Cs) is a hydrothermal mineral. It was found in a quartz-pectolite aggregate in quartzolite boulders. Associated minerals are quartz, pectolite, baratovite, aegirine, leucosphenite, pyrochlore, neptunite, fluorapophyllite-(K) and reedmergnerite.

\section{Appearance and Physical Properties}

In the quartz-pectolite aggregate, fluorapophyllite-(Cs) occurs as separate grains up to $0.08 \mathrm{~mm}$ across (Fig. 1) and as zones in grains of fluorapophyllite-(K) (grains of fluorapophyllite-(K) are up to 0.2 $\mathrm{mm}$ across). Individual grains of fluorapophyllite-(Cs) are irregular in shape.

Fluorapophyllite-(Cs) is colourless, it has a vitreous luster and a white streak. Cleavage is perfect; it is brittle and has a stepped fracture. The microhardness of fluorapophyllite-(Cs) is $\mathrm{VHN}_{100}=480$ $\mathrm{kg} / \mathrm{mm}^{2}$ (with the range of 468-502) which corresponds to a Mohs hardness of 4.5-5. $D_{\text {meas. }}=2.54(2)$ $\mathrm{g} / \mathrm{cm}^{3}$ as determined by floatation in Clerici liquid; $D_{\text {calc. }}=2.513 \mathrm{~g} / \mathrm{cm}^{3}$ (from the empirical formula). Fluorapophyllite-(Cs) is unixial $(+)$ with refractive indices $(\lambda=589 \mathrm{~nm}) \omega=1.540(2), \varepsilon=1.544(2)$. It is non-pleochroic. The compatibility index $(1-\mathrm{Kp} / \mathrm{Kc})=-0.002$ (for $\left.D_{\text {calc. }}\right)$ and 0.010 (for $D_{\text {meas. }}$ ), and is rated as superior (Mandarino 1981).

\section{Chemical Composition}

A grain of fluorapophyllite-(Cs) was analyzed with a JEOL 773 electron microprobe operating in wavelength-dispersive mode with an accelerating voltage of $20 \mathrm{kV}$, a specimen current of $20 \mathrm{nA}$, and a 
beam diameter of $3 \mu \mathrm{m}$. The following standards were used: Si, Al, K: microcline USNM 143966; Na: omphacite USNM 110607; Ca: anothite USNM 110607; Cs: $\mathrm{Cs}_{2} \mathrm{Nb}_{4} \mathrm{O}_{11}$; F: fluoro-phlogopite. The data were reduced and corrected by the PAP method of Pouchou \& Pichoir (1985). Table 1 gives the chemical composition of fluorapophyllite-(Cs), (mean of 10 points). The empirical formula based on $29(\mathrm{O}+\mathrm{F})$ $a p f u\left(\mathrm{H}_{2} \mathrm{O}=8 p f u\right.$ was calculated from crystal-structure refinement $)$ is $\left(\mathrm{Cs}_{0.75} \mathrm{~K}_{0.24}\right)_{\Sigma 0.99}$ $\left(\mathrm{Ca}_{3.99} \mathrm{Na}_{0.01}\right)_{\Sigma 4}\left(\mathrm{Si}_{8.01} \mathrm{Al}_{0.01}\right)_{\Sigma 8.02} \mathrm{O}_{20.03} \mathrm{~F}_{0.97}\left(\mathrm{H}_{2} \mathrm{O}\right)_{8}, Z=2$. The simplified formula is $(\mathrm{Cs}, \mathrm{K})(\mathrm{Ca}, \mathrm{Na})_{4}(\mathrm{Si}, \mathrm{Al})_{8} \mathrm{O}_{20} \mathrm{~F}\left(\mathrm{H}_{2} \mathrm{O}\right)_{8}$. The ideal formula is $\mathrm{CsCa}_{4} \mathrm{Si}_{8} \mathrm{O}_{20} \mathrm{~F}\left(\mathrm{H}_{2} \mathrm{O}\right)_{8}$ which requires $\mathrm{SiO}_{2}$ 48.03, $\mathrm{CaO} 22.41, \mathrm{Cs}_{2} \mathrm{O}$ 14.07, $\mathrm{H}_{2} \mathrm{O}$ 14.40, F 1.90, $-\mathrm{O}=\mathrm{F}_{2}-0.80$ total 100 wt.\%.

\section{DAta COLleCtion AND STRUCTURE REFinemENT}

Single-crystal X-ray data for fluorapophyllite-(Cs) were collected with a Bruker D8 QUEST ECO CMOS diffractometer equipped with a fine-focus tube $(\mathrm{MoK} \alpha)$ and a PHOTON 50 detector. The crystal does not diffract very well and that is why we cut the data at $2 \Theta=47.95^{\circ}$ (collected up to $2 \Theta=60.00^{\circ}$ ). X-ray powder diffraction data were obtained by collapsing the experimental single-crystal data into two dimensions (Table 2). Unit-cell parameters from the single-crystal data were determined by least-squares refinement of 5962 reflections with $I>10 \sigma I$ and are given in Table 3, together with miscellaneous information on data collection and structure refinement. For fluorapophyllite-(Cs), the intensities of 10527 reflections were measured using 60 s per $0.5^{\circ}$ frame. An absorption correction was done using the SADABS program (Sheldrick 2015). All calculations were done with the Bruker SHELXTL-2014/3 (version 3) system of programs (Sheldrick 2015).

The crystal structure of fluorapophyllite-(Cs) was refined using the atom coordinates of fluorapophyllite-(K) (Ståhl et al. 1987) as a starting model. The crystal structure of fluorapophyllite-(Cs) was refined to $R_{1}=4.31 \%$ based on 498 unique reflections with $\left(F_{\mathrm{o}}>4 \sigma F\right)$. Scattering curves for neutral atoms were taken from the International Tables for Crystallography (Wilson 1992). Site-scattering values were refined for the $A$ and $B$ sites with the scattering curves of $\mathrm{Cs}$ and $\mathrm{Ca}$, respectively. For the final refinement, the $\mathrm{D}$ (donor)- $\mathrm{H}(1,2)$ distances were softly constrained to $0.98 \AA$. 
Final atom coordinates and anisotropic displacement parameters are listed in Table 4, selected interatomic distances and $\mathrm{Si}-\mathrm{O}-\mathrm{Si}$ angles are given in Table 5, refined site-scattering and assigned sitepopulations for selected cation and anion sites are given in Table 6, details of hydrogen bonding are given in Table 7 and bond-valence values in Table 8. A Crystallography Information File (CIF) may be obtained from The Depository of Unpublished Data on the MAC website [documents Fluorapophyllite(Cs) CM_XXX].

\section{STRUCTURE DESCRIPTION}

In the crystal structure of fluorapophyllite-(Cs), there is one $T$ site occupied solely by $\mathrm{Si}$ and tetrahedrally coordinated by $\mathrm{O}$ atoms, $\langle\mathrm{T}-\mathrm{O}\rangle=1.615 \AA$. $\mathrm{SiO}_{4}$ tetrahedra link to form a $\left(\mathrm{Si}_{8} \mathrm{O}_{20}\right)^{8-}$ sheet perpendicular to [001]; in a sheet, $\mathrm{SiO}_{4}$ tetrahedra form 4- and 8-membered rings (Fig. 2). Between the Si-O sheets, there are two cation sites: $A$ and $B$. The Cs-dominant $A$ site is coordinated by eight $\mathrm{H}_{2} \mathrm{O}$ groups [O(4) site], with A-O(4) = 3.152(4) $\AA$ (Table 5); the $A$ site contains $\mathrm{Cs}_{0.75} \mathrm{~K}_{0.24} \square_{0.01}$, ideally $\mathrm{Cs}_{1}$ apfu (Table 6). The Cs-O bondlength of $3.152 \AA$ is definitely larger than the $\mathrm{K}-\mathrm{O}$ bondlength of 2.966-

$2.971 \AA$ in fluorapophyllite-(K) (Table 9). The Ca-dominant ${ }^{[7]} B$ site contains $\mathrm{Ca}_{3.99} \mathrm{Na}_{0.01}$, ideally $\mathrm{Ca}_{4}$ apfu; the $B$ site is coordinated by four $\mathrm{O}$ atoms, two $\mathrm{H}_{2} \mathrm{O}$ groups and one $\mathrm{F}$ atom, with $\langle\mathrm{B}-\varphi\rangle=2.420 \AA$ $\left(\varphi=\mathrm{O}, \mathrm{F}, \mathrm{H}_{2} \mathrm{O}\right)$ (Tables 5,6). The $\mathrm{Si}-\mathrm{O}$ sheets connect via A and $\mathrm{B}$ polyhedra and hydrogen bonding (Fig. 2). The geometry of hydrogen bonding is in accord with the geometry of hydrogen bonding in fluorapophyllite-(K) (Chao 1971, Ståhl et al. 1987).

We write the ideal formula of fluorapophyllite-(Cs) as the sum of cation and anion sites (Table 6), $\mathrm{CsCa}_{4}\left(\mathrm{Si}_{8} \mathrm{O}_{20}\right) \mathrm{F}\left(\mathrm{H}_{2} \mathrm{O}\right)_{8}, Z=2$. Fluorapophyllite-(Cs) is isostructural with fluorapophyllite-(K) and is a Csanalogue of fluorapophyllite-(K) (Table 9).

\section{ACKNOWLEDGEMENTS}

We thank Associate Editor Jim Evans and an anonymous reviewer for the comments which helped to improve the manuscript. We thank David Herbert (Department of Chemistry, University of 
Manitoba) for use of the Bruker D8 QUEST ECO CMOS diffractometer for collection of the singlecrystal X-ray data for fluorapophyllite-(Cs), and Mark A. Cooper for processing the single-crystal data. This work was supported by a Graduate Fellowship from the University of Manitoba to Maxwell C. Day and by a Discovery grant from the Natural Sciences and Engineering Research Council of Canada and by Innovation Grants from the Canada Foundation for Innovation to Frank C. Hawthorne. 


\section{REFERENCES}

Agakhanov, A.A., Pautov L.A., Sokolova, E., Hawthorne, F.C., Karpenko, V.Yu., Siidra, O.I., \& Muftakhov, V.A. (2017a) Odigitriaite, $\mathrm{CsNa}_{5} \mathrm{Ca}_{5}\left[\mathrm{Si}_{14} \mathrm{~B}_{2} \mathrm{O}_{38}\right] \mathrm{F}_{2}$, a new cesium borosilicate mineral from the Darai-Pioz alkaline massif, Tajikistan: Description and crystal structure. Mineralogical Magazine 81, 113-122.

Agakhanov, A.A., Pautov L.A., Sokolova, E., Hawthorne, F.C., Karpenko, V.Yu., Siidra, O.I., \& Garanin, V.K. (2017b) Mendeleevite-(Nd), $(\mathrm{Cs}, \square)_{6}(\square, \mathrm{Cs})_{6}(\square, \mathrm{K})_{6}(\operatorname{REE}, \mathrm{Ca})_{30}\left(\mathrm{Si}_{70} \mathrm{O}_{175}\right)$ $\left(\mathrm{OH}, \mathrm{H}_{2} \mathrm{O}, \mathrm{F}\right)_{35}$, a new mineral from the Darai-Pioz alkaline massif, Tajikistan. Mineralogical Magazine 81, 135-141.

Agakhanov, A.A., Pautov, L.A., Pekov, I.V., Karpenko, V.Y., Siidra, O.I., Sokolova, E., Hawthorne, F.C., Muftakhov, V.A., \& Kasatkin, A.V. (2017c) Gorbunovite, IMA 2017-040. Mineralogical Magazine 81, 1280.

Anthony J.W., Bideaux R.A., Bladh K.W., \& Nichols M.C. (1995) Handbook of Mineralogy. II. Silica, Silicates. Part 1. Tucson: Mineral Data Publishing, p.259.

Belakovskiy, D.I. (1991) Die seltenen Mineralien von Dara-i-Pioz im Hochgebirge Tadshikistans. Lapis 16(12), 42-48.

Brown, I.D. (1981) The bond valence method: an empirical approach to chemical structure and bonding. In Structure and Bonding in Crystals II (M. O’Keeffe \& A. Navrotsky, eds.). Academic Press, New York, N.Y., 357pp., (1-30).

Brown, I.D. \& Altermatt, D. (1985) Bond-valence parameters obtained from a systematic analysis of the inorganic crystal structure database. Acta Crystallographica B41, 244-247.

Cámara, F., Sokolova, E., Abdu, Y., \& Hawthorne, F.C. (2010) The crystal structures of niobophyllite, kupletskite-(Cs) and Sn-rich astrophyllite; revisions to the crystal chemistry of the astrophyllitegroup minerals. Canadian Mineralogist 48, 1-16.

Chao, G.Y. (1971) The refinement of the crystal structure of apophyllite. II Determination of the hydrogen positions by X-ray diffraction. American Mineralogist 56, 1234-1242. 
Dunn, P.J. \& W.E. Wilson (1978) Nomenclature revisions in the apophyllite group: hydroxyapophyllite, apophyllite, fluorapophyllite. Mineralogical Record 3, 95-98.

Dusmatov, V.D. (1968) On mineralogy of one alkaline massif. In Alkaline Rocks of Kirgizia and Kazakhstan. Ilym, Frunze (134-135) [in Russian].

Dusmatov, V.D. (1971) Mineralogy of the Darai-Pioz Alkaline Massif (Southern Tien-Shan). PhD dissertation, Institute of Mineralogy, Geochemistry and Crystal Chemistry of Rare Elements, Moscow, 171 p. [in Russian].

Faiziev, A.R., Gafurov, F.G., \& Sharipov B.N. (2010) Carbonatites of the Darai-Pioz alkaline massif, Central Tadjikistan, and their compositional features. Geochemistry International 48(11), 10841096.

Hatert, F., Mills, S.J., Pasero, M., \& Williams, P.A. (2013) CNMNC guidelines for the use of suffixes and prefixes in mineral nomenclature, and for the preservation of historical names. European Journal of Mineralogy 25, 113-115.

Mandarino, J.A. (1981) The Gladstone-Dale relationship. IV. The compatibility concept and its application. Canadian Mineralogist 41, 989-1002.

Matsueda, H., Miura, Y., \& Rucklidge, J. (1981) Natroapophyllite, a new orthorhombic sodium analog of apophyllite. Description, occurrence and nomenclature. American Mineralogist 66, 410-423.

Moskvin, A.V. (1937) Geography and Geology of East Karategin. In Tajik-Pamir expedition of 1935. Academy of Sciences of USSR, Moscow-Leningrad (682-739) [in Russian].

Pautov, L.A., Agakhanov, A.A., Pekov, I.V., Karpenko, V.Y., Siidra, O.I., Sokolova, E., Hawthorne, F.C., \& Faiziev, A.R. (2017) Garmite, IMA 2017-008. Mineralogical Magazine 81, 740.

Pouchou, J.L. \& Pichoir, F. (1985) 'PAP' $\varphi(\rho Z)$ procedure for improved quantitative microanalysis. In Microbeam Analysis (J.T. Armstrong, ed.). San Francisco Press, San Francisco, California (104106). 
Reguir, E.P., Chakhmouradian, A.R., \& Evdokimov, M.D. (1999) The mineralogy of a unique baratoviteand miserite-bearing quartz - albite - aegirine rock from the Dara-i-Pioz complex, northern Tajikistan. Canadian Mineralogist 37, 1369-1384.

Semenov, E.I. \& Dusmatov, V.D. (1975) On mineralogy of the Darai-Pioz alkaline massif (Central Tajikistan). Doklady Akademii nauk Tadzhikskoi SSR, XVIII (11), 39-41 [in Russian].

Sheldrick, G.M. (2015) Crystal Structure refinement with SHELX. Acta Crystallographica C71, 3-8.

Ståhl, K., Kvick, Å., \& Ghose, S. (1987) A neutron diffraction and thermogravimetric study of the hydrogen bonding and dehydration behaviour in fluorapophyllite, $\mathrm{KCa}_{4}\left(\mathrm{Si}_{8} \mathrm{O}_{20}\right) \mathrm{F} \cdot 8 \mathrm{H}_{2} \mathrm{O}$, and its partially dehydrated form. Acta Crystallographica B43, 517-523.

Wilson, A.J.C., Ed. (1992) International Tables for Crystallography. Volume C: Mathematical, physical and chemical tables. Kluwer Academic Publishers, Dordrecht, The Netherlands.

Yefimov, A.F., Dusmatov, V.D., Ganzeyev, A.A., \& Katayeva, Z.T. (1971) Cesium kupletskite, a new mineral. Doklady of the Academy of Sciences U.S.S.R., Earth Sciences 197, 140-143. 


\section{Figure CAPTIONS}

Fig. 1. BSE image of fluorapophyllite-(Cs) (1) in quartz (2) - pectolite (3) aggregate.

Fig. 2. General view of the crystal structure of fluorapophyllite-(Cs). Si tetrahedra and Ca-dominant polyhedra are orange and pale blue; $\mathrm{Cs}$ atom ( $A$ site) is shown as a large pink sphere; $\mathrm{F}$ atom is shown as a small yellow sphere, $\mathrm{O}$ atom of the $\mathrm{H}_{2} \mathrm{O}$ group at the $\mathrm{O}(4)$ site is shown as a medium red sphere and $\mathrm{H}$ atoms as small gray spheres. Bonds $\mathrm{O}(4)-\mathrm{H}$ and $\mathrm{H}$-acceptor are shown as black solid and dashed lines, respectively. Thin black lines show the unit cell. 
TABLE 1. CHEMICAL COMPOSITION AND UNIT FORMULA*

FOR FLUORAPOPHYLLITE-(Cs)

\begin{tabular}{lllll}
\hline \multicolumn{2}{l}{ Constituent wt.\% } & Range & & apfu \\
\hline $\mathrm{SiO}_{2}$ & 48.78 & $48.25-49.08$ & $\mathrm{Si}$ & 8.01 \\
$\mathrm{Al}_{2} \mathrm{O}_{3}$ & 0.05 & $0.00-0.12$ & $\mathrm{Al}$ & 0.01 \\
$\mathrm{CaO}$ & 22.69 & $22.32-22.83$ & $\mathrm{Ca}$ & 3.99 \\
$\mathrm{Cs}{ }_{2} \mathrm{O}$ & 10.71 & $9.67-11.81$ & $\mathrm{Cs}$ & 0.75 \\
$\mathrm{~K}_{2} \mathrm{O}$ & 1.13 & $0.72-1.46$ & $\mathrm{~K}$ & 0.24 \\
$\mathrm{Na}_{2} \mathrm{O}$ & 0.04 & $0.00-0.09$ & $\mathrm{Na}$ & 0.01 \\
$\mathrm{H}_{2} \mathrm{O}$ & $14.61^{* *}$ & & & \\
$\mathrm{~F}$ & 1.86 & $1.65-2.18$ & $\mathrm{~F}$ & 0.97 \\
$\mathrm{~F}=\mathrm{O}$ & $\frac{-0.78}{99.09}$ & & $\mathrm{H}{ }_{2} \mathrm{O}$ & 8.00 \\
Total & 99.09 & & \\
\hline
\end{tabular}

*formula unit calculated on $29(\mathrm{O}+\mathrm{F})$ pfu;

${ }^{* *}$ calculated from crystal-structure analysis: $\mathrm{H}_{2} \mathrm{O}=8 \mathrm{pfu}$. 
TABLE 2. X-RAY POWDER DIFFRACTION DATA* FOR FLUORAPOPHYLLITE-(Cs)

\begin{tabular}{|c|c|c|c|c|c|c|c|c|c|}
\hline lest. & $d_{\text {calc }}(\AA)$ & $h$ & $k$ & I & lest. & $d_{\text {calc }}(\AA)$ & $h$ & $k$ & I \\
\hline \multirow[t]{2}{*}{100} & 7.8705 & 0 & 0 & 2 & & 2.0259 & 4 & 2 & 0 \\
\hline & 7.8522 & 1 & 0 & 1 & 14 & 1.9662 & 2 & 1 & 7 \\
\hline 10 & 6.4064 & 1 & 1 & 0 & & 1.9639 & 3 & 2 & 5 \\
\hline \multirow[t]{2}{*}{38} & 4.5405 & 1 & 0 & 3 & & 1.9619 & 4 & 2 & 2 \\
\hline & 4.5300 & 2 & 0 & 0 & 6 & 1.9185 & 4 & 1 & 4 \\
\hline \multirow[t]{3}{*}{100} & 3.9352 & 0 & 0 & 4 & 25 & 1.8012 & 4 & 2 & 4 \\
\hline & 3.9261 & 2 & 0 & 2 & & 1.8001 & 5 & 0 & 1 \\
\hline & 3.9239 & 2 & 1 & 1 & & 1.8001 & 4 & 3 & 1 \\
\hline 55 & 3.6024 & 2 & 1 & 2 & 25 & 1.7700 & 2 & 1 & 8 \\
\hline 28 & 3.3532 & 1 & 1 & 4 & & 1.7689 & 3 & 1 & 7 \\
\hline \multirow[t]{2}{*}{24} & 3.2069 & 2 & 1 & 3 & & 1.7658 & 4 & 3 & 2 \\
\hline & 3.2032 & 2 & 2 & 0 & 13 & 1.7173 & 1 & 0 & 9 \\
\hline \multirow[t]{3}{*}{84} & 2.9738 & 1 & 0 & 5 & & 1.7144 & 4 & 0 & 6 \\
\hline & 2.9669 & 2 & 2 & 2 & & 1.7127 & 5 & 0 & 3 \\
\hline & 2.9659 & 3 & 0 & 1 & & 1.7127 & 4 & 3 & 3 \\
\hline 12 & 2.8650 & 3 & 1 & 0 & 10 & 1.6766 & 2 & 2 & 8 \\
\hline \multirow[t]{2}{*}{11} & 2.8229 & 2 & 1 & 4 & & 1.6729 & 5 & 2 & 1 \\
\hline & 2.8187 & 3 & 1 & 1 & 15 & 1.6220 & 3 & 1 & 8 \\
\hline 37 & 2.6922 & 3 & 1 & 2 & & 1.6194 & 5 & 1 & 4 \\
\hline 73 & 2.5146 & 3 & 1 & 3 & 20 & 1.6058 & 2 & 1 & 9 \\
\hline \multirow[t]{2}{*}{71} & 2.4860 & 2 & 1 & 5 & & 1.6035 & 4 & 2 & 6 \\
\hline & 2.4842 & 2 & 2 & 4 & & 1.6021 & 5 & 2 & 3 \\
\hline 19 & 2.4278 & 1 & 1 & 6 & & 1.6016 & 4 & 4 & 0 \\
\hline \multirow[t]{3}{*}{25} & 2.1825 & 1 & 0 & 7 & 13 & 1.5741 & 0 & 0 & 10 \\
\hline & 2.1794 & 3 & 0 & 5 & & 1.5704 & 5 & 0 & 5 \\
\hline & 2.1767 & 4 & 0 & 2 & 16 & 1.5538 & 5 & 3 & 0 \\
\hline \multirow[t]{2}{*}{42} & 2.1189 & 3 & 1 & 5 & & 1.5492 & 3 & 2 & 8 \\
\hline & 2.1179 & 3 & 2 & 4 & & 1.5470 & 5 & 2 & 4 \\
\hline 14 & 2.0609 & 3 & 3 & 2 & 7 & 1.5135 & 3 & 0 & 9 \\
\hline 45 & 2.0296 & 2 & 2 & 6 & & 1.5100 & 6 & 0 & 0 \\
\hline
\end{tabular}

*Powder data were obtained by collapsing experimental single-crystal data into two dimensions. The most intense reflection (101) was covered by the beam stop. Therefore intensity of (101) was calculated from the refined crystal structure and all intensities rescaled accordingly. Reflections with lest $<5$ are not listed. 
TABLE 3. MISCELLANEOUS REFINEMENT DATA FOR FLUORAPOPHYLLITE-(Cs)

\begin{tabular}{|c|c|}
\hline$a(\AA)$ & $9.060(6)$ \\
\hline c & $15.741(11)$ \\
\hline$V\left(\AA^{3}\right)$ & $1292.10(19)$ \\
\hline Space group & $P 4 / m n c$ \\
\hline$z$ & 2 \\
\hline Reflections $(I>10 \sigma /)$ & 5962 \\
\hline Absorption coefficient $\left(\mathrm{mm}^{-1}\right)$ & 2.41 \\
\hline$F(000)$ & 973.9 \\
\hline$D_{\text {calc. }}\left(\mathrm{g} / \mathrm{cm}^{3}\right)$ & 2.513 \\
\hline Crystal size (mm) & $0.045 \times 0.040 \times 0.030$ \\
\hline Radiation/monochromator & MoKa/graphite \\
\hline $2 \theta$-range for data collection $\left({ }^{\circ}\right)$ & $60.00,47.95^{\star}$ \\
\hline $\begin{array}{l}h^{*} \\
k^{*} \\
l^{*}\end{array}$ & $\begin{array}{l}-10 \leq h \leq 10 \\
-10 \leq k \leq 10 \\
-18 \leq I \leq 18\end{array}$ \\
\hline$R$ (int) & $0.0564^{*}$ \\
\hline Reflections collected & $10527^{*}$ \\
\hline $\begin{array}{l}\text { Independent reflections } \\
F_{0}>4 \sigma F\end{array}$ & $\begin{array}{l}539^{*} \\
498^{*}\end{array}$ \\
\hline Refinement method & $\begin{array}{l}\text { Full-matrix least squares } \\
\text { on } F^{2} \text {, fixed weights } \\
\text { proportional to } 1 / \sigma F_{o}^{2}\end{array}$ \\
\hline \multicolumn{2}{|l|}{ Final $R$ (obs) } \\
\hline$R_{1}\left(F_{0}>4 \sigma F\right)$ & 0.0431 \\
\hline$R_{1}$ & 0.0487 \\
\hline$w R_{2}$ & 0.0851 \\
\hline \multicolumn{2}{|c|}{ Highest peak, deepest hole $\left(\mathrm{e} \AA^{-3}\right) 0.42,-0.52$} \\
\hline Goodness of fit on $F^{2}$ & 1.276 \\
\hline
\end{tabular}

${ }^{*}$ structure refinement (see text). 
TABLE 4. ATOM COORDINATES AND ANISOTROPIC DISPLACEMENT PARAMETERS ( $\left.\AA^{2}\right)$ FOR FLUOROAPOPHYLLITE-(Cs)

\begin{tabular}{|c|c|c|c|c|c|c|c|c|c|c|}
\hline Atom & $x$ & $y$ & $z$ & $U^{n 1}$ & $U^{22}$ & $U^{\beta 3}$ & $U^{23}$ & $U^{13}$ & $U^{12}$ & $U^{e q}$ \\
\hline$A$ & 0 & 0 & $1 / 2$ & $0.0196(6)$ & $0.01960(6)$ & $0.0814(13)$ & 0 & 0 & 0 & $0.0402(6)$ \\
\hline B & $0.10274(14)$ & $0.24597(14)$ & 0 & $0.0059(7)$ & $0.0071(7)$ & $0.0063(7)$ & 0 & 0 & $0.0013(5)$ & $0.0064(4)$ \\
\hline $\mathrm{Si}$ & $0.22099(13)$ & $0.09073(13)$ & $0.19063(7)$ & $0.0053(7)$ & $0.0046(7)$ & $0.0061(7)$ & $-0.0011(5)$ & $-0.0016(5)$ & $-0.0001(5)$ & $0.0053(4)$ \\
\hline $\mathrm{O}(1)$ & $0.3567(3)$ & $0.1433(3)$ & $1 / 2$ & $0.0071(14)$ & $0.0071(14)$ & $0.009(2)$ & $0.0010(14)$ & $0.0010(14)$ & $0.0011(18)$ & $0.0078(10)$ \\
\hline $\mathrm{O}(2)$ & $0.0790(3)$ & $0.1897(3)$ & $0.2190(2)$ & $0.0103(18)$ & $0.0109(17)$ & $0.0145(18)$ & $-0.0002(14)$ & $0.0010(14)$ & $0.0023(13)$ & $0.0119(8)$ \\
\hline $\mathrm{O}(3)$ & $0.2578(4)$ & $0.1068(4)$ & $0.09251(19)$ & $0.0101(17)$ & $0.0128(18)$ & $0.0081(16)$ & $-0.0027(14)$ & $-0.0007(13)$ & $0.0006(13)$ & $0.0103(8)$ \\
\hline $\mathrm{O}(4)$ & $0.1940(5)$ & $0.4493(4)$ & $0.0907(2)$ & $0.040(2)$ & $0.0115(19)$ & $0.0136(18)$ & $-0.0029(15)$ & $-0.0023(17)$ & $0.0010(17)$ & $0.0217(9)$ \\
\hline$F$ & 0 & 0 & 0 & $0.007(2)$ & $0.007(2)$ & $0.028(5)$ & 0 & 0 & 0 & $0.0142(18)$ \\
\hline$H(1)$ & $0.219(5)$ & $0.427(5)$ & $0.1498(10)$ & & & & & & & $0.02601(0)$ \\
\hline $\mathrm{H}(2)$ & $0.153(5)$ & $0.549(2)$ & $0.085(3)$ & & & & & & & $0.02601(0)$ \\
\hline
\end{tabular}


TABLE 5. SELECTED INTERATOMIC DISTANCES $(\AA ̊)$

AND ANGLES $\left(^{\circ}\right)$ FOR FLUOROAPOPHYLLITE-(Cs)

\begin{tabular}{|c|c|c|c|c|}
\hline \multirow{2}{*}{\multicolumn{2}{|c|}{$\overline{A-O}(4) a \times \varepsilon$}} & \multirow[t]{2}{*}{$3.152(4)$} & $\mathrm{T}-\mathrm{O}(3)$ & $1.587(3)$ \\
\hline & & & $\mathrm{T}-\mathrm{O}(1)$ & $1.616(2)$ \\
\hline $\mathrm{B}-\mathrm{O}(3)$ & $x 4$ & 2.395(3) & $\mathrm{T}-\mathrm{O}(2) \mathrm{b}$ & $1.626(3)$ \\
\hline B-F & & $2.415(2)$ & $\mathrm{T}-\mathrm{O}(2)$ & $1.631(3)$ \\
\hline $\mathrm{B}-\mathrm{O}(4)$ & $x 2$ & $2.473(4)$ & $\langle\mathrm{T}-\mathrm{O}\rangle$ & 1.615 \\
\hline \multirow[t]{4}{*}{$\langle B-\varphi\rangle$} & & 2.420 & & \\
\hline & & & $\mathrm{T}-\mathrm{O}(1)-\mathrm{Tc}$ & $141.5(3)$ \\
\hline & & & $\mathrm{T}-\mathrm{O}(2)-\mathrm{Tc}$ & $140.1(2)$ \\
\hline & & & $<\mathrm{T}-\mathrm{O}-\mathrm{T}\rangle$ & 140.8 \\
\hline
\end{tabular}

${ }^{*} \varphi=\mathrm{O}, \mathrm{F}, \mathrm{H}_{2} \mathrm{O}$.

Symmetry operators: a: $-x+1 / 2, y-1 / 2,-z+1 / 2$;

b: $y,-x, z ; c:-y, x, z$. 
TABLE 6. REFINED SITE-SCATTERING VALUES AND ASSIGNED SITE-POPULATIONS FOR FLUOROAPOPHYLLITE-(Cs)

\begin{tabular}{|c|c|c|c|c|c|}
\hline Site* $^{*}$ & $\begin{array}{l}\text { Refined } \\
\text { site-scattering } \\
\text { (epfu) }\end{array}$ & $\begin{array}{l}\text { Site population } \\
\text { (apfu) }\end{array}$ & $\begin{array}{l}\text { Calculated } \\
\text { site-scattering } \\
\text { (epfu) }\end{array}$ & $\begin{array}{l}<\mathrm{Ct}-\varphi>_{\text {obs. }} \\
(\AA \AA A)^{*}\end{array}$ & $\begin{array}{l}\text { Ideal } \\
\text { composition } \\
\text { (apfu) }\end{array}$ \\
\hline \multicolumn{6}{|c|}{ Cations } \\
\hline${ }^{[8]} A$ & $45.0(3)$ & $\mathrm{Cs}_{0.75} \mathrm{~K}_{0.24} \square_{0.01}$ & 45.81 & 3.152 & Cs \\
\hline${ }^{[7]} B$ & 80.0 & $\mathrm{Ca}_{3.99} \mathrm{Na}_{0.01}$ & 79.91 & 2.420 & $\mathrm{Ca}_{4}$ \\
\hline${ }^{[4]} T$ & 112.0 & $\mathrm{Si}_{8.00}$ & 112.00 & 1.615 & $\mathrm{Si}_{8}$ \\
\hline \multicolumn{6}{|c|}{ Anions and $\mathrm{H}_{2} \mathrm{O}$ groups } \\
\hline$[2,2,4] \mathrm{O}(1,2,3)$ & & $\mathrm{O}_{20}$ & & & $\mathrm{O}_{20}$ \\
\hline${ }^{[4]} \mathrm{F}$ & & $\mathrm{F}_{0.97} \square_{0.03}$ & & & $\mathrm{~F}$ \\
\hline $\mathrm{O}(4)$ & & $\left(\mathrm{H}_{2} \mathrm{O}\right)_{8}$ & & & $\left(\mathrm{H}_{2} \mathrm{O}\right)_{8}$ \\
\hline
\end{tabular}

${ }^{*} \mathrm{Ct}=$ cation, $\varphi=\mathrm{O}, \mathrm{F}, \mathrm{H}_{2} \mathrm{O}$. 
TABLE 7. HYDROGEN BONDING IN FLUOROAPOPHYLLITE-(Cs)

\begin{tabular}{llllll}
\hline $\mathrm{D}-\mathrm{H} \ldots \mathrm{A}$ & $\begin{array}{l}\mathrm{D}-\mathrm{H} \\
(\AA)\end{array}$ & $\begin{array}{l}\mathrm{H} \ldots \mathrm{A} \\
(\AA)\end{array}$ & $\begin{array}{l}\mathrm{D} \ldots \mathrm{A} \\
(\AA)\end{array}$ & $\begin{array}{l}\angle \mathrm{DHA} \\
\left({ }^{\circ}\right)\end{array}$ & $\begin{array}{l}\angle \mathrm{HDH} \\
\left({ }^{\circ}\right)\end{array}$ \\
\hline $\mathrm{O}(4)-\mathrm{H}(1) \ldots \mathrm{O}(2) \mathrm{a}$ & $0.98(1)$ & $2.23(1)$ & $3.186(5)$ & $167(4)$ & $111(4)$ \\
$\mathrm{O}(4)-\mathrm{H}(1) \ldots \mathrm{O}(3) \mathrm{b}$ & $0.98(1)$ & $1.81(1)$ & $2.769(5)$ & $167(4)$ & \\
\hline
\end{tabular}

a: $x-1 / 2,-y+1 / 2, z+1 / 2 ;$ b: $y,-x+1, z$. 
TABLE 8. BOND-VALENCE VALUES* FOR FLUOROAPOPHYLLITE-(Cs)

\begin{tabular}{|c|c|c|c|c|c|c|}
\hline Atom** & $A$ & $B$ & $\mathrm{~T}$ & $H(1)$ & $\mathrm{H}(2)$ & $\Sigma$ \\
\hline $\mathrm{O}(1)$ & & & $1.02^{\times 2 \rightarrow}$ & & & 2.04 \\
\hline $\mathrm{O}(2)$ & & & $\begin{array}{l}0.99 \\
0.98\end{array}$ & 0.09 & & 2.06 \\
\hline $\mathrm{O}(3)$ & & $0.30^{\times 4 \downarrow} \times 2-$ & 1.10 & & 0.19 & 1.89 \\
\hline $\mathrm{O}(4)$ & $0.14^{\times 8 \downarrow}$ & $0.25^{\times 2 \downarrow}$ & & 0.91 & 0.81 & 2.11 \\
\hline$F$ & & $0.23^{\times 4 \rightarrow}$ & & & & 0.92 \\
\hline$\Sigma$ & 1.10 & 1.93 & 4.09 & 1.00 & 1.00 & \\
\hline
\end{tabular}

* bond-valence parameters ( $v u$ ) are from Brown (1981), except Brown \& Altermatt (1985) for $\mathrm{H}-\mathrm{O}$;

${ }^{* *} \mathrm{~A}=\mathrm{Cs} ; \mathrm{B}=\mathrm{Ca} ; \mathrm{T}=\mathrm{Si} ; \mathrm{O}(4)=\mathrm{O}$ atom of an $\mathrm{H}_{2} \mathrm{O}$ group. 
TABLE 9. COMPARISON OF F-MEMBERS OF THE APOPHYLLITE GROUP

\begin{tabular}{|c|c|c|c|c|}
\hline Mineral & Fluorapophyllite-(Cs) & \multicolumn{2}{|c|}{ Fluorapophyllite-(K) } & Fluorapophyllite-(Na) \\
\hline $\begin{array}{l}\text { End-member } \\
\text { formula, } Z=2\end{array}$ & $\mathrm{CsCa}_{4}\left(\mathrm{Si}_{8} \mathrm{O}_{20}\right) \mathrm{F}\left(\mathrm{H}_{2} \mathrm{O}\right)_{8}$ & \multicolumn{2}{|c|}{$\mathrm{KCa}_{4}\left(\mathrm{Si}_{8} \mathrm{O}_{20}\right) \mathrm{F}\left(\mathrm{H}_{2} \mathrm{O}\right)_{8}$} & $\mathrm{NaCa}_{4}\left(\mathrm{Si}_{8} \mathrm{O}_{20}\right) \mathrm{F}\left(\mathrm{H}_{2} \mathrm{O}\right)_{8}$ \\
\hline $\begin{array}{l}\text { Crystal system } \\
\text { Space group }\end{array}$ & $\begin{array}{l}\text { Tetragonal } \\
P 4 / m n c\end{array}$ & \multicolumn{2}{|l|}{$\begin{array}{l}\text { Tetragonal } \\
P 4 / m n c\end{array}$} & $\begin{array}{l}\text { Orthorhombic } \\
\text { Pnnm }\end{array}$ \\
\hline $\begin{array}{l}a(\AA) \\
b \\
C \\
V\left(\AA^{3}\right)\end{array}$ & $\begin{array}{l}9.060 \\
9.060 \\
15.741 \\
1292.1\end{array}$ & $\begin{array}{l}8.965^{\star} \\
8.965^{\star} \\
15.767^{\star} \\
1267.2^{\star}\end{array}$ & $\begin{array}{l}8.970^{\star *} \\
8.970^{\star *} \\
15.792^{\star \star} \\
1270.6^{\star *}\end{array}$ & $\begin{array}{l}8.875 \\
8.881 \\
15.79 \\
1236.9\end{array}$ \\
\hline $\begin{array}{l}\text { A-site dominant } \\
\text { cation } \\
\mathrm{A}-\mathrm{H}_{2} \mathrm{O}(\AA)\end{array}$ & $\begin{array}{l}\text { Cs } \\
3.152 \times 8\end{array}$ & $2.971^{*} \times 8$ & $2.966^{* *} \times 8$ & $\begin{array}{l}\mathrm{Na} \\
2.763 \times 4: 2.854 \times 4\end{array}$ \\
\hline Optical data & $\begin{array}{l}\text { Uniaxial }(+) \\
\omega=1.540 \\
\varepsilon=1.544\end{array}$ & \multicolumn{2}{|c|}{$\begin{array}{l}\text { Uniaxial }(+) \\
\omega=1.530-1.536 \\
\varepsilon=1.532-1.538\end{array}$} & $\begin{array}{l}\text { Biaxial }(-) \\
\alpha=1.536 \\
\beta=1.538 \\
\gamma=1.544\end{array}$ \\
\hline $\begin{array}{l}D_{\text {meas. }}\left(\mathrm{g} \mathrm{cm}^{-3}\right) \\
D_{\text {calc. }}\left(\mathrm{g} \mathrm{cm}^{-3}\right)\end{array}$ & $\begin{array}{l}2.54 \\
2.513\end{array}$ & \multicolumn{2}{|l|}{$\begin{array}{l}2.33-2.37 \\
2.37\end{array}$} & $\begin{array}{l}2.50 \\
2.30\end{array}$ \\
\hline References & This work & \multicolumn{2}{|c|}{$\begin{array}{l}{ }^{*} \text { Chao (1971); } \\
{ }^{* \star} \text { Ståhl et al. (1987); } \\
\text { Anthony et al. (1995) }\end{array}$} & Matsueda et al. (1981) \\
\hline
\end{tabular}




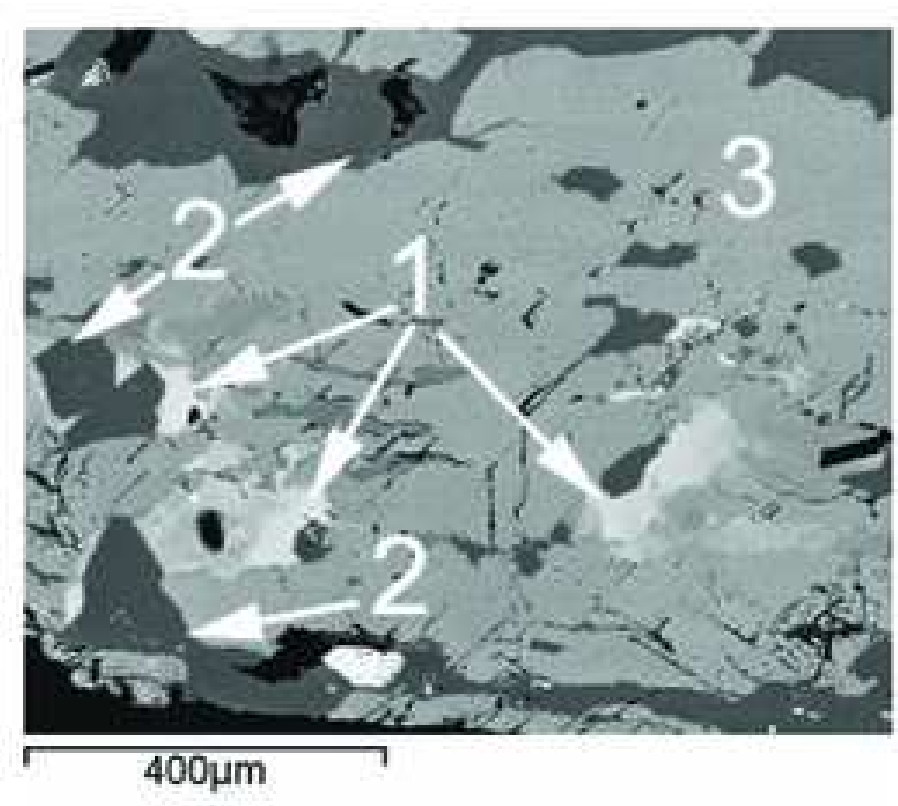

Fig. 1

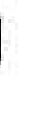

ad;Figure;Fig. 1.tiff $\underline{\underline{\Perp}}$




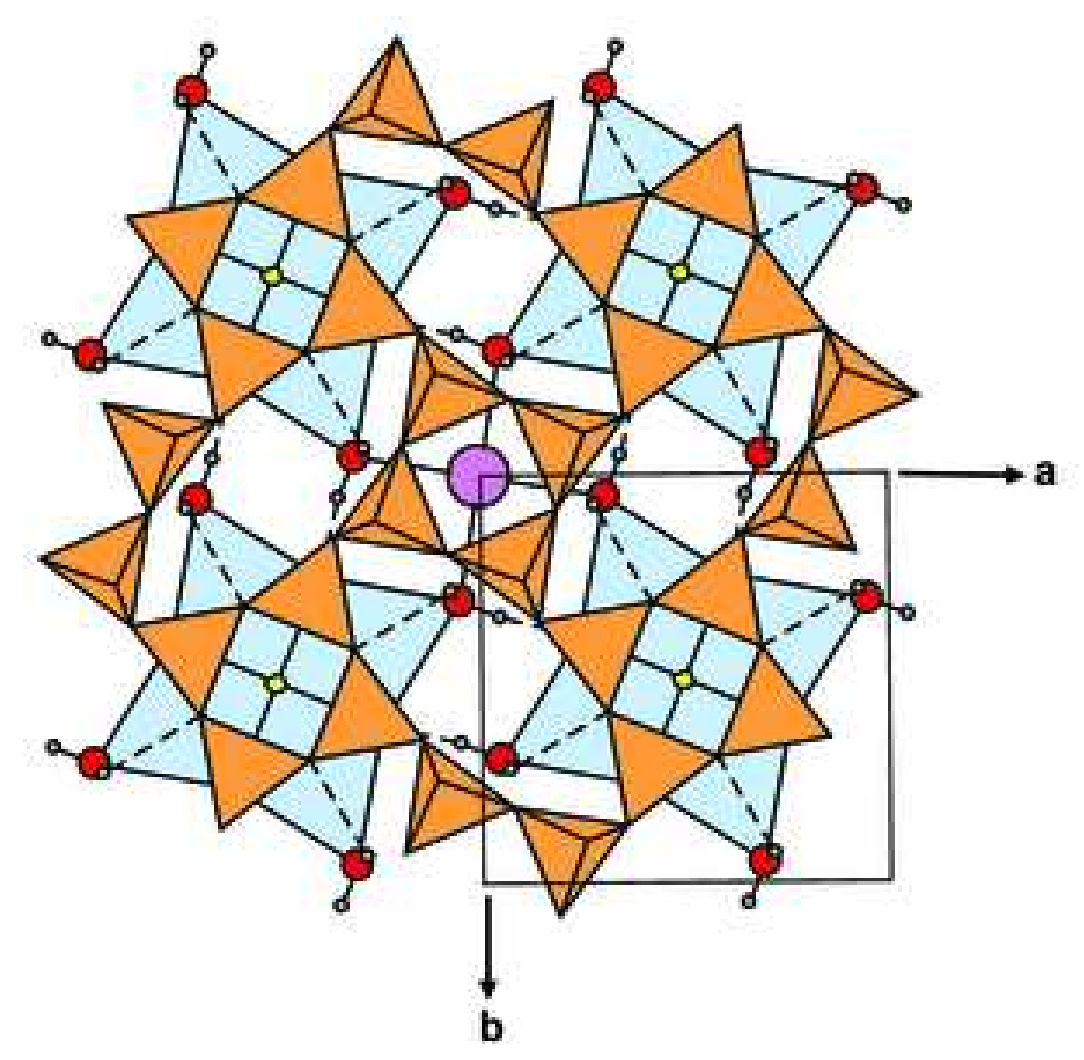

Fig. 2 


\section{Click here to access/download CIF File \\ FLUORAPOPHYLLITE-\%28Cs\%29.cif \\ CIF File}

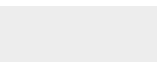

10

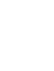

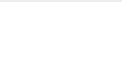

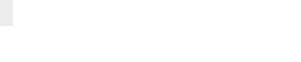

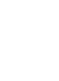


Click here to access/download Other 2018-108a FLUORAPOPHYLLITE-\%28Cs\%29_IMA.pdf 